\title{
PENGEMBANGAN MODUL PRAKTIKUM GENETIKA BERBASIS KETERAMPILAN PROSES SAINS UNTUK MAHASISWA PROGRAM STUDI PENDIDIKAN BIOLOGI
}

\author{
Etty Nurmala Fadillah ${ }^{1}$, Erni Angraini ${ }^{2}$ \\ ${ }^{1}$ Universitas Muhammadiyah Palembang, Jl. Jendral A. Yani 13 Ulu, Kota Palembang \\ e-mail: ettynurmalafadillah@um-palembang.ac.id
}

\begin{abstract}
The development of this practicum module is based on overcoming student difficulties in practicum implementation and final report making. Skillsbased modules of the science process to practice the skills of the process of science are observing, grouping, interpreting, predicting, formulating hypotheses, planning experiments, and communicating. This module is expected to lead the students to be actively involved in carrying out practicum activities independently related to the concept of the material to be studied. The purpose of this research is to produce teaching material product in the form of practical genetic module based on skill of science process that is feasible and practical used by students in genetic lecturing. Procedure of development in this research with 4-D model proposed by Thiagarajan that is define (definition), design (design), develop (development), and disseminate (dissemination). Data collection instruments used in the form of interviews and assessment questionnaire. Data analysis techniques used qualitative analysis by calculating the average score of each component of the module assessment and calculating practicality data on the use of the practicum module. The science-based genetic module of the science process module is appropriate for use by professors of materials experts, media experts, and linguists. Second, module practicum based on science skill based on students' responses have practicality in practicum practice that is $76,05 \%$ module contents, $76,26 \%$ presentation, and $76,10 \%$ from language.
\end{abstract}

Keywords: practical modules, science process skills.

\section{PENDAHULUAN}

Fakultas Keguruan dan Ilmu Pendidikan Universitas Muhammadiyah Palembang (FKIP UM Palembang) merupakan salah satu Lembaga Pendidikan dan Tenaga Kependidikan (LPTK) yang diharapkan dapat menghasilkan lulusan dengan kemampuan akademis yang baik. Oleh karena itu, FKIP UM Palembang harus senantiasa mengikuti perkembangan ilmu pengetahuan dan teknologi yang berkembang dengan pesat guna melakukan penyegaran dan pembaharuan terutama terhadap aktivitas dan proses pembelajaran yang berlangsung di dalamnya. Proses pembelajaran yang berlangsung di FKIP UM Palembang tidak hanya sekedar pemberian materi, topik ataupun konsep-konsep yang strategis, tetapi juga harus memberikan pengalaman belajar yang memungkinkan berkembangnya kemandirian mahasiswa untuk belajar.

Program studi pendidikan biologi merupakan salah satu program studi yang ada di FKIP UM Palembang. Pembelajaran biologi merupakan suatu ilmu pengetahuan yang tidak terlepas dari fakta, konsep, dalil dan prinsip yang berkaitan dengan makhluk hidup serta interaksinya dengan lingkungan. 
Ilmu biologi memerlukan pemahaman, aplikasi, analisis, sintesis, dan evaluasi atau berpikir tingkat tinggi. Kemampuankemampuan tersebut diperoleh melalui salah satu kegiatan praktikum yang hampir di tiap semester atau mata kuliah pasti ada. Hal ini, pada program studi pendidikan biologi terdapat mata kuliah yang bertujuan untuk menganalisis serta mempraktekkan langsung kerja di laboratorium. Salah satunya matakuliah tersebut adalah Genetika.

Genetika merupakan salah satu matakuliah pada Program Studi Pendidikan Biologi FKIP UM Palembang yang bertujuan agar mahasiswa memahami lebih jauh tentang genetik. Matakuliah ini memiliki kompetensi yang harus dicapai oleh mahasiswa. Ketercapaian kompetensi tersebut didukung oleh banyak faktor. Salah satu faktor yang mampu menunjang ketercapaian kompetensi pada mata kuliah ini pelaksanaan praktikum. Pada saat pelaksanaan praktikum, maka perlu adanya modul praktikum.

Permasalahan yang ditemukan dari hasil pengamatan dan wawancara yang dilakukan terhadap mahasiswa program studi pendidikan biologi FKIP UM Palembang khususnya dalam perkuliahan Genetika adalah pada saat melaksanakan perkuliahan praktikum, mahasiswa belum memiliki bahan ajar praktikum yang memadai untuk proses pembelajaran yang kondusif, khususnya modul praktikum berbentuk cetak.

Salah satu faktor yang dapat menunjang kemandirian mahasiswa dalam belajar adalah ketersediaan bahan ajar cetak berbentuk modul praktikum genetika. Melalui penggunaan modul praktikum genetika diharapkan mahasiswa termotivasi untuk belajar mandiri, sehingga perkuliahan akan lebih efektif dan efisien karena mahasiswa mampu memahami sendiri materi perkuliahan yang akan dipelajari. Mahasiswa aktif dalam belajar karena modul praktikum genetika berisi langkah kerja yang dapat melibatkan mahasiswa, sehingga tidak perlu menunggu dosen untuk menjelaskan pelaksanaan praktikum. Melalui modul, mahasiswa diharapkan mampu melaksanakan praktikum tanpa bantuan sepenuhnya dari dosen.

Modul yang akan dikembangkan pada penelitian ini adalah modul berbasis keterampilan proses sains. Keterampilan Proses Sains (KPS) biasa digunakan oleh para ilmuwan dalam melakukan penyelidikan ilmiah ke dalam rangkaian proses pembelajaran. Science process skills are the basic skills of facilitating learning in science, allowing students to be active, developing a sense of responsibility, increasing the permanence of learning and providing research methods(Gurses et al., 2014), yang dapat diartikan bahwa keterampilan proses sains adalah keterampilan dasar yang memfasilitasi pembelajaran dalam ilmu sains, memungkinkan siswa untuk aktif, mengembangkan rasa tanggung jawab, meningkatkan pembelajaran dan metode penelitian.

Keterampilan proses sains tidak dapat dipisahkan dari pemahaman konseptual dalam proses pembelajaran sains. Keterampilan proses sains adalah cara ilmiah yang membimbing peneliti untuk berpikir (Gezer, 2014), sedangkan menurut pendapat beberapa ahli keterampilan proses adalah keterampilan yang melibatkan keterampilanketerampilan kognitif atau intelektual, manual dan sosial (Rustaman, 2005). Ada juga menyatakan bahwa keterampilan proses sains adalah refleksi dari metode yang digunakan oleh para ilmuan untuk menghasilkan informasi tentang ilmu pengetahuan (Sheeba, 2013). Indikator keterampilan proses sains yang diukur dalam modul praktikum pada keterampilan dasar 
yang meliputi (a) mengamati, mengelompokkan, (c) menafsirkan,

(b) sebagai langkah awal penelitian. Angket meramalkan, (e) merumuskan hipotesis, (f) merencanakan percobaan, dan mengkomunikasikan (Rustaman, 2005).

Modul ini diharapkan mampu menuntun mahasiswa untuk terlibat aktif dalam melaksanakan kegiatan praktikum secara mandiri yang terkait dengan konsep materi yang akan dipelajari. Salah satu harapannya adalah untuk menghasilkan produk bahan ajar berupa modul praktikum genetika berbasis keterampilan proses sains yang dapat digunakan oleh mahasiswa dalam perkuliahan genetika.

\section{METODE PENELITIAN}

Penelitian yang berjudul pengembangan modul praktikum genetika berbasis keterampilan proses sains untuk mahasiswa program studi pendidikan biologi ini merupakan Research and Development $(R \& D) . \quad$ Penelitian ini bertujuan mengembangkan modul praktikum genetika berbasis keterampilan proses sains. Model pengembangan yang digunakan dalam penelitian ini adalah model pengembangan 4D (Four-D) yaitu definel pendefinisian, design/ perancangan, develop/ pengembangan, dan disseminatel penyebarluasan (Thiagarajan, 1974).

Pelaksanaan penelitian ini pada bulan Januari - Juni 2017 di FKIP UM Palembang. Populasi dalam penelitian ini adalah Mahasiswa Program studi Pendidikan Biologi. Sampelnya adalah mahasiswa program studi pendidikan biologi semester VI tahun 2017.

Teknik pengumpulan data berupa non tes. Teknik non tes dengan melalui wawancara dan angket. Wawancara digunakan untuk mengetahui informasi terkait pelaksanaan praktikum. Hasil wawancara ini dijadikan need assessment yang digunakan yakni angket penilaian modul oleh dosen ahli materi, dosen media, dan bahasa serta angket kepraktisan yang diisi oleh mahasiswa.

Produk bahan aja yang dikembangkan adalah berupa modul praktikum berbasis keterampilan proses sains. Produk ini divalidasi secara teori terlebih dahulu oleh tiga validator yaitu ahli materi, ahli media, dan ahli bahasa. Selanjutnya divalidasi secara empiris dalam uji coba terbatas dengan jumlah mahasiswa 35 orang untuk melihat kepraktisan penggunaan modul praktikum ini.

Teknik analisis data yaitu pada draf awal yang divalidasi menghasilkan data kualitatif.

1. Data validasi teman sejawat dan pakar.

Penilaian kelayakan modul meliputi tiga komponen, yaitu: isi, bahasa, dan penyajian. Analisis data dari kelayakan modul dalam penelitian ini mengacu pada BSNP 2007 yaitu:

a. Menghitung rata-rata skor dari setiap komponen penilaian modul.

Skor yang diperoleh dari setiap butir subkomponen penilaian modul di hitung reratanya. Jika rerata skor tersebut telah didapatkan maka dapat di hitung rerata skor komponen penilaian modul, dengan rumus sebagai berikut:

$$
x=\frac{\sum x}{N}
$$

Keterangan:

$$
\begin{array}{ll}
\mathrm{x} & =\text { skor rata-rata } \\
\sum \mathrm{x} & =\text { jumlah skor } \\
\mathrm{N} & =\text { jumlah butir/ sub komponen }
\end{array}
$$

b. Menetapkan kriteria penilaian modul Kriteria penilaian ahli, modul dinyatakan layak apabila komponen kelayakan isi mempunyai rata-rata skor minimal 2,75 
pada setiap subkomponen, sedangkan pada komponen kebahasaan dan penyajian mempunyai rata-rata skor lebih besar dari 2,50 pada setiap subkomponen. modul dinyatakan layak dengan perbaikan apabila komponen isi, kebahasaan dan penyajian mempunyai rata-rata skor kurang dari atau sama dengan 2.50 pada setiap subkomponen. modul dinyatakan tidak layak apabila mempunyai rata-rata skor sama dengan 1 pada semua komponen. Kriteria penilaian disajikan pada Tabel 1.

Tabel 1. Kriteria Penilaian Validasi Ahli

\begin{tabular}{lcl}
\hline \multicolumn{1}{c}{ Komponen } & Skor & \multicolumn{1}{c}{ Kriteria } \\
\hline Isi & $\mathrm{x} \geq 2,75$ & Layak \\
& $\mathrm{x}>2,5$ & Layak \\
Penyajian dan kebahasaan & $\mathrm{x} \leq 2,5$ & Layak dengan perbaikan \\
& $\mathrm{x}=1$ & Tidak Layak \\
\hline (Sumber: BSNP, 2007) & &
\end{tabular}

2. Data tanggapan mahasiswa.

Analisis data dari angket tanggapan mahasiswa diukur dengan menggunakan skala Likert. Skala pengukuran dengan tipe ini, akan didapat jawaban yang tegas, yaitu ya atau tidak (Sugiyono, 2009). Data yang telah diperoleh kemudian dihitung dengan rumus (Sudijono, 2009) sebagai berikut:

$$
P=\frac{f}{n} x 100 \%
$$

Keterangan:

$\mathrm{P} \quad=$ persentase

$\mathrm{f} \quad=$ jumlah skor yang didapat

$\mathrm{n} \quad=$ jumlah skor maksimal

Hasil persentase skor akan dikonversikan berdasarkan kriteria (Arikunto \& Cepi, 2009) sebagai berikut:

Tabel 2.Kriteria Angket Tanggapan Mahasiswa

\begin{tabular}{cc}
\hline Persentase & Kriteria \\
\hline $76-100$ & Sangat baik \\
$51-75$ & Baik \\
$26-50$ & Kurang baik \\
$\leq 25$ & Tidak baik \\
\hline
\end{tabular}

\section{HASIL DAN PEMBAHASAN}

Hasil dari penelitian ini berupa data kelayakan modul praktikum genetika berbasis keterampilan proses sains dan tanggapan mahasiswa terhadap modul praktikum tersebut. Pertama, tahap define bertujuan untuk menetapkan dan mendefinisikan kebutuhan dalam penilaian keterampilan siswa. Tahapan ini dilakukan dengan studi wawancara kepada mahasiswa pendidikan biologi FKIP UM Palembang.
Hasil yang diperoleh merupakan masalah yang timbul dalam pelaksanaan praktikum seringkali mereka tidak memiliki panduan atau modul praktikum. Hal ini menyebabkan terkadang terjadi beberapa kesalahankesalahan terkait langkah kerja dalam pelaksanaan praktik serta dalam pembuatan laporan akhir, sehingga beberapa mahasiswa mengharapkan adanya panduan atau modul praktikum disaat mereka melaksanakan praktik di laboratorium. Modul sangat diperlukan dalam kegiatan praktikum, selain sebagai penuntun praktikum modul dapat dirancang untuk mengarahkan mahasiswa mampu bekerja dengan langkah-langkah 
yang ilmiah (Furqan dkk, 2016). Modul praktikum yang berbasis keterampilan proses sains ini ingin melihat keterampilanketerampilan mahasiswa pada saat pelaksanaan kegiatan praktikum di laboratorium. Modul berbasis KPS ini dibuat sebagai buku pegangan untuk belajar mandiri yang didalamnya terdapat eksperimeneksperimen sehingga dapat dilakukan secara mandiri (Rosa, 2015).

Kedua, tahap design yaitu Tahap ini berisi perancangan model dan prosedur pengembangan. Pada tahapan ini dilakukan perancangan modul praktikum genetika berbasis keterampilan proses sains untuk mahasiswa program studi pendidikan biologi FKIP UM Palembang. Tahapan ini berupa menentukan deskripsi matakuliah, tujuan matakuliah, pokok bahasan, dan indikator keterampilan proses sains. Deskripsi matakuliah, tujuan matakuliah, dan pokok bahasan yang sudah biasa dilaksanakan dalam materi pembelajaran pada matakuliah genetika. Keterampilan proses sains yang digunakan adalah keterampilan dasar yaitu berupa mengamati, mengelompokkan, menafsirkan, meramalkan, merumuskan hipotesis, merencanakan percobaan, dan mengkomunikasikan. Dibuktikan dengan video proses pelaksanaan praktikum serta dokumentasi. Modul berbasis KPS dapat meningkatkan kompetensi keterampilan dan presentase yang tinggi dari siswa menunjukkanbahwa keterampilan proses telah membuat mereka sadar mengenai relevansi dari sains dalam kehidupan mereka (Mei, 2007).

Tahap ketiga develop, yaitu uji coba produk awal yang dilakukan yaitu tahap validasi ahli yaitu terdiri dari tiga ahli, antara lain: ahli materi, ahli media, dan ahli bahasa. Validasi ahli dilakukan oleh tiga orang dosen di FKIP Universitas Muhammadiyah Palembang.

Validasi oleh ahli materi mencakup enam indikator penilaian dengan skor terendah adalah 1 dan skor maksimal adalah 4. Hasil validasi ahli materi dapat dilihat pada Tabel 3 .

Tabel 3. Lembar Penilaian yang diberikanOleh Dosen Ahli Materi

\begin{tabular}{clc}
\hline No & \multicolumn{1}{c}{ Indikator Penilaian } & Skor \\
\hline 1. & Kesesuaian materi dengan deskripsi mata kuliah & 3,33 \\
2. & Keakuratan materi & 2,50 \\
3. & Kemuktahiran materi & 3,50 \\
4. & Konsep dasar & 3,11 \\
5. & Sistematika penyampaian materi & 3,00 \\
6. & Materi dapat meningkatkan Keterampilan Proses Sains & 3,43 \\
\hline
\end{tabular}

Indikator 1. kesesuaian materi dengan

Pengembangan modul ini mengangkat materi tentang dengan tujuan pembelajaran. Modul ini juga berisi tentang hasil validasi modul yang dilakukan oleh ahli materi menyatakan layak. Penilaian kelayakan modul dengan beberapa indikator yang dinilai. deskripsi mata kuliah terdiri dari butir penilaian yaitu a) kelengkapan materi, b) keluasan materi, dan c) kedalaman materi. Dari skor yang diberikan maka diperoleh skor rerata 3,33 dengan kriteria layak. Indikator 2. keakuratan materi terdiri dari a) keakuratan konsep dan definisi, b) keakuratan prinsip, c) keakuratan fakta dan data, d) keakuratan gambar, diagram, dan ilustrasi, e) keakuratan notasi, simbol, dan 
ikon, f) keakutaran acuan pustaka diperoleh rerata skor 2,50 dengan kriteria layak dengan perbaikan. Saran yang diberikan adalah diharapkan gambar atau ilustarasi lebih diperjelas, notasi yang digunakan sebaiknya konsisten.

Indikator 3. kemutahiran materi terdiri dari a) kesesuaian materi dengan perkembangan ilmu b) gambar diagram dan ilutrasi aktual diperoleh rerata skor 3,50 dengan kriteria layak.

Indikator 4. konsep dasar terdiri dari kesesuaian konsep: a) mengenal lalat buah, b) pembuatan media lalat buah, c) persilangan hibrid pada lalat buah, d) simulasi kromosom manusia, e) kromosom tumbuhan, f) peranan gen yang dipengaruhu seks, g) konsep alel ganda, h) simulasi berangkai dan pindah silang, dan i) bioinformatika diperoleh rerata skor 3,11 dengan kriteria layak.

Indikator 5. sistematika penyampaian materi dari materi umum ke khusus dengan skor rerata 3,00 kriteria layak. Sedangkan indikator 6. Materi dapat meningkatkan keterampilan proses sains yaitu mengamati, mengelompokkan, menafsirkan, meramalkan, berhipotesis, merencanakan percobaan, dan mengkomunikasikan dengan rerata skor 3,43 kriteria layak.

Validasi oleh ahli media mencakup tiga komponen indikator penilaian dengan skor terendah adalah 1 dan skor maksimal adalah 4. Hasil validasi ahli media dapat dilihat pada Tabel 4.

Tabel 4. Lembar Penilaian yang Diberikan Oleh Dosen Ahli Media

\begin{tabular}{clc}
\hline No & \multicolumn{1}{c}{ Indikator Penilaian } & Skor \\
\hline 1. & Ukuran Modul & 3,50 \\
2. & Desain Sampul Modul (Cover) & 3,11 \\
3. & Desain Isi Modul & 3,29 \\
\hline
\end{tabular}

Berdasarkan Tabel 4, ahli media menyatakan penilaian atau kelayakan modul dengan beberapa indikator yang dinilai. Terkait 1. ukuran modul terdiri dari a) kesesuaian ukuran modul dengan standar ISO, dan b) kesesuaian ukuran dengan materi isi dengan modul diperoleh skor rerata 3,50 dengan kriteria layak.

Indikator 2. desain sampul modul (cover) terdiri dari a) penampilan unsur tata letak pada sampul muka, belakang dan punggung secara harmonis memiliki irama dan kesatuan (unity) serta konsisten, b) menampilkan pusat pandang (center point) yang baik c) komposisi dan ukuran unsur tata letak (judul, pengarang, ilustrasi, logo, dll) proporsional, seimbang dan seirama dengan tata letak isi (sesuai pola), d) warna unsur tata letak harmonis dan memperjelas fungsi, e) ukuran huruf judul buku lebih dominan dan proporsional dibandingkan ukuran buku, nama pengarang, f) warna judul buku kontras dengan warna latar belakang, g) tidak menggunakan terlalu banyak kombinasi jenis huruf, h) menggambarkan isi/ materi ajar dan mengungkapkan karakter objek, dan i) bentuk, warna, ukuran, proporsi obyek sesuai dengan realita diperoleh rerata skor 3,11 dengan kriteria layak.

Indikator 3. desain isi modul terdiri dari a) penempatan unsur tata letak konsisten berdasarkan pola, b) Pemisahan antar paragraf jelas, c) bidang cetak dan margin proporsional, d) marjin dua halaman yang berdampingan proporsional, e) spasi antara teks dan ilustrasi sesuai, f) penempatan judul kegiatan belajar, sub judul kegiatan belajar, dan angka halaman/ folio tidak mengganggu pemahaman, g) penempatan ilustrasi dan keterangan gambar (caption) tidak 
mengganggu pemahaman, h) penempatan hiasan/ ilustrasi sebagai latar belakang tidak mengganggu judul, teks, angka halaman, i) penempatan judul, subjudul, ilustrasi, dan keterangan gambar tidak mengganggu pemahaman, j) tidak menggunakan terlalu banyak jenis huruf, k) penggunaan variasi huruf (bold, italic, all capital, small capital) tidak berlebihan, 1) lebar susunan teks normal, m) spasi antar baris susunan teks normal, 14) mampu mengungkap makna/ arti dari objek, n) bentuk akurat dan proporsional sesuai dengan kenyataan, o) penyajian keseluruhan ilustrasi serasi, dan p) kreatif dan dinamis ini diperoleh skor rerata 3,29 dengan kreteria layak.

Validasi oleh ahli bahasa menyatakan bahasa indonesia yang digunakan sangat baik dan benar begitupun kesesuaian bahasa serta peristilahan dan kejelasan bahasa dikategorikan baik. Hal ini tergambarkan pada Tabel 5.

\begin{tabular}{clc}
\multicolumn{2}{c}{ Tabel 5. Lembar Penilaian yang Diberilan Oleh Dosen Ahli Bahasa } \\
\hline No & \multicolumn{1}{c}{ Indikator Penilaian } & Skor \\
\hline 1. & Bahasa Indonesia yang baik dan benar & 4,00 \\
2. & Peristilahan & 3,00 \\
3. & Kejelasan bahasa & 3,00 \\
4. & Kesesuaian bahasa & 4,00 \\
\hline
\end{tabular}

Berdasarkan Tabel 5, ahli bahasa menyatakan penilaian atau kelayakan modul dengan beberapa indikator yang dinilai. Terkait indkator 1. bahasa indonesia yang baik dan benar yaitu a) menggunakan aturan EYD dan b)menggunakan kaidah Bahasa Indonesia yang baik dan benar dengan rerata skor 4,00 kriteria layak. Indikator peristilahan yaitu Menggunakan peristilahan yang sesuai dengan pokok bahasan dengan skor 3,00 kriteria layak. Indikator kejelasan bahasa yaitu bahasa yang digunakan sederhana, lugas, dan mudah dipahami siswa dengan skor 3,00 kreteria layak. Selanjutnya indikator 2. kesesuaian bahasa yaitu a) bahasa komunikatif, dan b) bahasa yang digunakan mengembangkan kemampuan berpikir siswa dalam memahami konsep Lingkungan dengan rerata skor 4,00 kriteria layak. Dari ketiga validator ini selanjutnya diperbaiki sesuai kritik dan sarannya. Modul dibuat berdasarkan program pembelajaran yang utuh dan sistematis serta dirancang untuk sistem pembelajaran mandiri (Munadi, 2010). Keterampilan proses sains merupakan bagian penting dari penyelidikan ilmiah akibatnya meningkatkan literasi sains di kalangan mahasiswa (Chabelangula, 2011).

Selain validasi kepada ahli materi, media dan bahasa, modul praktikum yang dikembangkan juga mendapat tanggapan dari mahasiswa terkait kepraktisan penggunaannya. Hasil tanggapan mahasiswa dapat dilihat pada Tabel 6.

Tabel 6. Lembar Tanggapan tentang Kepraktisan Modul Praktikum

\begin{tabular}{clc}
\hline No & \multicolumn{1}{c}{ Indikator Penilaian } & Persentase \\
\hline 1. & Isi modul & $76,05 \%$ \\
2. & Penyajian & $76,26 \%$ \\
3. & Bahasa/ Keterangan & $76,10 \%$ \\
\hline
\end{tabular}

dengan gambar yang jelas, c) gambar pada

Berdasarkan Tabel 6, indikator materi dilengkapi keterangan yang jelas, d) penilaian 1. Isi modul yaitu terdiri dari a) materi mudah dipahami, b) Materi didukung

aktivitas Mahasiswa mudah dilakukan, e) pemahaman isi modul memerlukan proses 
berfikir memdapat rerata persentase $76,05 \%$ dengan ktriteria sangat baik.

Indikator 2. penyajian terdiri dari a) tampilan isi modul menarik dan berwarna, b) judul dan keterangan gambar sesuai dengan gambar, c) gambar pada modul dilengkapi dengan sumbernya, d) penyajian modul runtut dan logis, e) penyajian modul mampu mengembangkan aspek mengamati, f) penyajian modul mampu mengembangkan aspek mengelompokkan, g) penyajian modul mampu mengembangkan aspek menafsirkan, h) penyajian modul mampu mengembangkan aspek meramalkan, i) penyajian modul mampu mengembangkan aspek berhipotesis, j) penyajian modul mampu mengembangkan aspek merencanakan percobaan, $\mathrm{k}$ ) penyajian modul mampu mengembangkan aspek mengkomunikasikan, dan 1) Petunjuk penggunaan modul jelas dengan rerata persentase $76,26 \%$ dengan kriteria sangat baik.

Indikator 3. bahasa/keterangan yaitu a) bahasa yang digunakna mudah dipahami, b) bahasa komunikatif, dan c) penulisan kata benar dengan rerata persentase 76,10\% kriteria sangat baik. Persentase terendah pada indikator penilaian nomor 1 dan tertinggi pada nomor 2. Tanggapan mahasiswa masuk dalam kategori sangat baik. Atau dengan kata lain praktis digunakan. Menurut Setiawati (2013) modul yang mendapat skor dengan kriteria sangat baik dapat digunakan untuk uji coba

Tahap keempat Disseminate yaitu penyebarluasan produk hasil akhir pengembangan ke seluruh populasi. Pada tahap ini akan dilakukan penyebarluasan produk modul praktikum pada bulan Maret 2018 yaitu Semester VI terdiri dari kelas A dan B.

\section{SIMPULAN DAN SARAN}

Simpulannya adalah Pertama, modul praktikum genetika berbasis keterampilan proses sains layak digunakan menurut dosen ahli materi, ahli media, dan ahli bahasa. Kedua, modul praktikum genetika berbasis keterampilan proses sains berdasarkan tanggapan mahasiswa memiliki kepraktisan dalam melaksanakan praktikum yaitu $76,05 \%$ isi modul, $76,26 \%$ penyajian, dan $76,10 \%$ dari bahasa.

Sarannya adalah Modul praktikum genetika ini masih perlu beberapa komponen diperbaiki, perlunya penambahan penilaian validator sehingga banyak masukkan dan saran yang membuat modul ini semakin baik atau layak dan semakin praktis digunakan oleh mahasiswa, serta penambahan lembar penilaian untuk keterampilan proses sains

\section{RUJUKAN}

Arikunto, S \& S.A.J. Cepi. (2009). Evaluasi Program Pendidikan. Jakarta: Bumi Aksara.

BSNP. (2007). Media Komunikasi dan Dialog Standar Pendidikan. Buletin BSNP, 2 (1): 22.

Chabelangula, Mweene Vivien. (2011). How Pre-service Teacher's Understand and Perform Science Process Skills. Eurasia Journal of Mathematics Science \& /technology Education, 8(3), 167-176 ISSN: 1305-8223.

Furqan, H., Yusrizal. Samiran. (2016). Pengembangan Model Praktikum Berbasis Inkuiri untuk Meningkatkan Keterampilan Proses Sains dan Hasil Belajar Siswa kKelas $X$ di SMA Negeri 1 Bukit Bener Meriah. Jurnal Pendidikan Sains Imdonesia, 4(2), 124129.

Gezer, S.U. (2014). A Case Study on Preservice Science Teachers' Laboratory Usage Self Efficacy and Scientific Process Skills, ProcediaSocial and Behavioral Sciences, 174, 1158-1165. 
Mei, Yew Teo Grace. (2007). Promoting Science Process Skills and the Relevance of Science ALIVE! Programme. Proceedings of Redesigning Pedagogy: Culture, Knowladge and Understanding Conference,Singapore. Environmental \& Science Education. 3(1), 30-34 ISSN 1306-3065.

Muhadi, Yudhi. (2010). Media Pembelajaran. Jakarta: Gaung Persada Press.

Rosa, Friska Octavia. (2015). Pengembangan Modul Pembelajaran IPA SMP pada Materi Tekanan Berbasis Keterampilan Proses Sains. Jurnal Pendidikan Fisika, 3(1), 49-63.

Rustaman, N.Y. (2005). Strategi belajar mengajar biologi. Malang: Penerbit Universitas Negeri Malang

Sheeba, M.N. (2013). An Anatomy of Science Process Skills In The Light of The Challenges to Realize Science Instruction Leading to Global Excellence in Education. Educationia Confab, 2, 108-123.
Setiawati, R. (2013). Pengambangan Modul Berbasis Inkuiri Terbimbing untuk Mengoptimalkan Sikap Ilmiah Peserta Didik pada Pokok Bahasan Listrik Dinamis di SMAN 8 Purworejo Kelas X Tahun 2012/2013. Jurnal Radiasi, 3(1).

Sudijono. (2009). Pengantar Evaluasi Pendidikan. Jakarta: Rajawali.

Sugiyono. (2009). Model Penelitian Kuantitatif, Kualitatif dan $R \& D\left(8^{\text {th }}\right.$ ed).Bandung: Alfabeta.

Thiagarajan, S., D.S. \& Semmel, M.I. (1974). Instructional Developmnt for Training Teachers of Exceptional Children. Minneapolis: University of Minneasota. 